\title{
INCREASING INDICATORS OF EFFECTIVENESS OF THE HIGHER EDUCATIONAL INSTITUTION BY REGULATION OF THE THRESHOLD SCORES OF THE UNIFIED STATE EXAMINATION
}

\author{
Alexey Ivanovich Pykhtin*, Oleg Victorovich Ovchinkin \\ Southwest State University, Kursk, Russia
}

The paper describes improving the efficiency of educational activities of higher education institutions on the example of enrolment to the South-west state university in 2015-2017. The main efficiency criterion of educational activity is grade-point average evaluation of persons accepted for full-time study. This criterion is set by the Ministry of Science and High Education of the Russian Federation. It is shown on the example of statistical data of the unified state examination in Kursk region in 2015-2018. The implementation of this criterion is determined by admission structure of higher education institutions (the list of specialties, entrance tests, state-funded places). Increasing of grade-point average is possible by threshold scores increasing for one or several subjects (entrance tests). The analysis shows that such approach allows GPA increasing of enrolled students but at the same time leads to income decrease of the educational organization due to the reduction of accepted students. There are diagrams that show dependence of GPA from threshold score change of such subjects as Russian language, Mathematics and other subjects. The diagrams also show income decline at increase in threshold scores in specified cases. GPA increase of the unified state examination by changing the threshold score is economically inappropriate as it influences other efficiency indicators (assessment of financial and economic activity, average salaries).

Key words: Applicant, Unified state examination, GPA, Minimum score, Efficiency

\section{INTRODUCTION}

Assessment of higher education institution activity is one of the questions which is paid special attention by the Ministry of Education and Science of the Russian Federation. Annual efficiency monitoring of higher education organizations which is carried out by the Department of state policy of higher education of the Ministry of Education and Science of the Russian Federation is an example (http://indicators.miccedu.ru/monitoring/). This monitoring defines 8 indicators of efficiency. A certain threshold is defined for each indicator. USE GPA of accepted full-time students not including state-funded students (threshold is 60 from 100) is the only criterion for final efficiency assessment.

This criterion is contradictory as it does not characterize quality of education and only to some extent estimates the level of applicants [1-5]. At the same time different structure of higher education institutions, list of entrance tests are not taking into account when estimating efficiency. But these factors are very important [6].

There is an order of the Ministry of Education and Science of the Russian Federation, 23.01.2018 №41 "About indicators of activity efficiency of federal budgetary and autonomous educational institutions of higher education and work of their heads who are under the Ministry of Education and Science of the Russian Federation" (further - Order 41). This order defines expanded list of efficiency indicators. Possible values and maximum scores are defined for each indicator. The score is appointed by experts of the Ministry of Education and Science of the Russian Federation in accordance with the indicators of Order 41. This indicator is the indicator defining overall effectiveness of higher education institution and its head. Threshold values are different for "federal" and "research" higher education institutions and for other educational organizations. Higher education institution can have 0 if an indicator is less than 60,15 if the value is between 60-65 scores and 20 if an indicator exceeds 65 . This is according to "GPA of the unified state examination for accepted full-time students who want to get bachelor degree and to study according to specialist program at state expense ".

\section{MATERIALS}

It is difficult to implement these indicators because most of applicants (75-85\%) are from the region. So, USE results are proportional to the USE results of the region. At the same time different universities have different USE subjects. So Physics (USE GPA for Kursk region 52.153.1) in combination with Mathematics (USE GPA for Kursk region 48.1-51.2) is common for higher education institutions in which the majority of specialties are natural-science or technical. Social science is the main subject for pedagogical or humanitarian higher education institutions. In Kursk region the GPA was higher by 3,9 points then in 2017. Besides it is the most popular subject after obligatory subjects such as Russian language and Mathematics. Table 1 shows USE results in Kursk region in 2015-2018 [7].

It is possible to increase USE GPA of the students ac- 
cepted on the first course implementing 2 main ways or their combination: 1) to increase minimum threshold scores in subjects which are necessary for university admission; 2) to stimulate applicants with high scores to choose higher education institution, offering them various grants, additional educational services and etc. [8-11]

\section{RESULTS AND DISCUSSION}

Figure 1 shows the increase impact in minimum threshold score in Russian language on GPA of enrolled students taking into account USE results. Russian language is chosen for the analysis because this subject is obligatory when applying to any field of study. It is also chosen because applicants have the highest GPA for several years.

Implementation of the first way generally leads to students' reduction (as applicants who do not overcome a threshold score in one or several subjects can lose an opportunity to enter the university) and thus there are financial losses for higher education institutions (fig. 2). Decline in income can be due to reduction of students studying according to contracts. And it can also be due to not filling the places financed by budgetary funds (It leads to decrease in the size of subsidy provided to high- er education institutions. Places are not filled because of increase in minimum threshold scores). So, for example, it was necessary to increase threshold score in Russian language from 39 to 67 to increase enrolled students into the Southwest state university (SWSU) in 2017. It was done to increase GPA from 60 to 65 . At the same time the number of enrolled students decreased from 1140 to approximately 430 people. It leaded to financial losses. The university could lose 35 million rubles at an average cost of study (80 thousand rubles a year).

Increase in threshold scores of all USE subjects can be more effective. It can be taken into account at admission to the university. Overcoming of high efficiency threshold score (65 scores) can be by minimum scores increase. This increase can be on 10 scores. Such results are made by the analysis of admission campaigns in SWSU in 2015-2017. Financial losses at the same time were 30 million rubles at decrease in number of first-year students on 400 people (fig. 4).

\section{ACKNOWLEDGEMENT}

The study is a part of presidential grant (MK-968.2018.8).

Table 1: USE results in Kursk regionof Russia in 2015-2018 [7]

\begin{tabular}{|c|c|c|c|c|c|}
\hline Subject & Indicator & 2015 & 2016 & 2017 & 2018 \\
\hline All subjects & Total number of participants & 5300 & 5250 & 4722 & 4890 \\
\hline \multirow{2}{*}{ Russian } & GPA & 66,1 & 70,4 & 70,2 & 72,0 \\
\hline & Number of participants & 5175 & 5142 & 4661 & 4777 \\
\hline \multirow{3}{*}{ Mathematics } & GPA & 50,2 & 51,2 & 48,7 & 49,9 \\
\hline & Number of participants & 4258 & 3910 & 3417 & 3365 \\
\hline & Unsatisfactory results, \% & 7,6 & 6,2 & 10,3 & 6,0 \\
\hline \multirow{3}{*}{ Social studies } & GPA & 54,8 & 51,7 & 57,0 & 55,8 \\
\hline & Number of participants & 3416 & 3383 & 2826 & 2865 \\
\hline & Unsatisfactory results, $\%$ & 13,3 & 18,1 & 10,0 & 14,8 \\
\hline \multirow{3}{*}{ Physics } & GPA & 52,2 & 52,1 & 53,1 & 51,6 \\
\hline & Number of participants & 1460 & 1497 & 1391 & 1314 \\
\hline & Unsatisfactory results, $\%$ & 4,0 & 2,6 & 2,7 & 5,2 \\
\hline \multirow{3}{*}{ History } & GPA & 51,0 & 53,2 & 54,4 & 54,2 \\
\hline & Number of participants & 1229 & 1256 & 1082 & 1086 \\
\hline & Unsatisfactory results, \% & 6,8 & 6,9 & 5,2 & 6,7 \\
\hline \multirow{3}{*}{ Informatics } & GPA & 50,7 & 53,9 & 55,6 & 54 \\
\hline & Number of participants & 335 & 278 & 313 & 355 \\
\hline & Unsatisfactory results, \% & 20,6 & 16,2 & 14,4 & 14,9 \\
\hline \multirow{3}{*}{ Chemistry } & GPA & 60,1 & 58,5 & 56,6 & 57,9 \\
\hline & Number of participants & 568 & 578 & 561 & 603 \\
\hline & Unsatisfactory results, $\%$ & 7,6 & 7,8 & 11,8 & 12,6 \\
\hline \multirow{3}{*}{ Biology } & GPA & 57,7 & 53,4 & 55,1 & 53,9 \\
\hline & Number of participants & 1143 & 1162 & 1018 & 1022 \\
\hline & Unsatisfactory results, \% & 9,5 & 13,5 & 11,1 & 12,2 \\
\hline
\end{tabular}




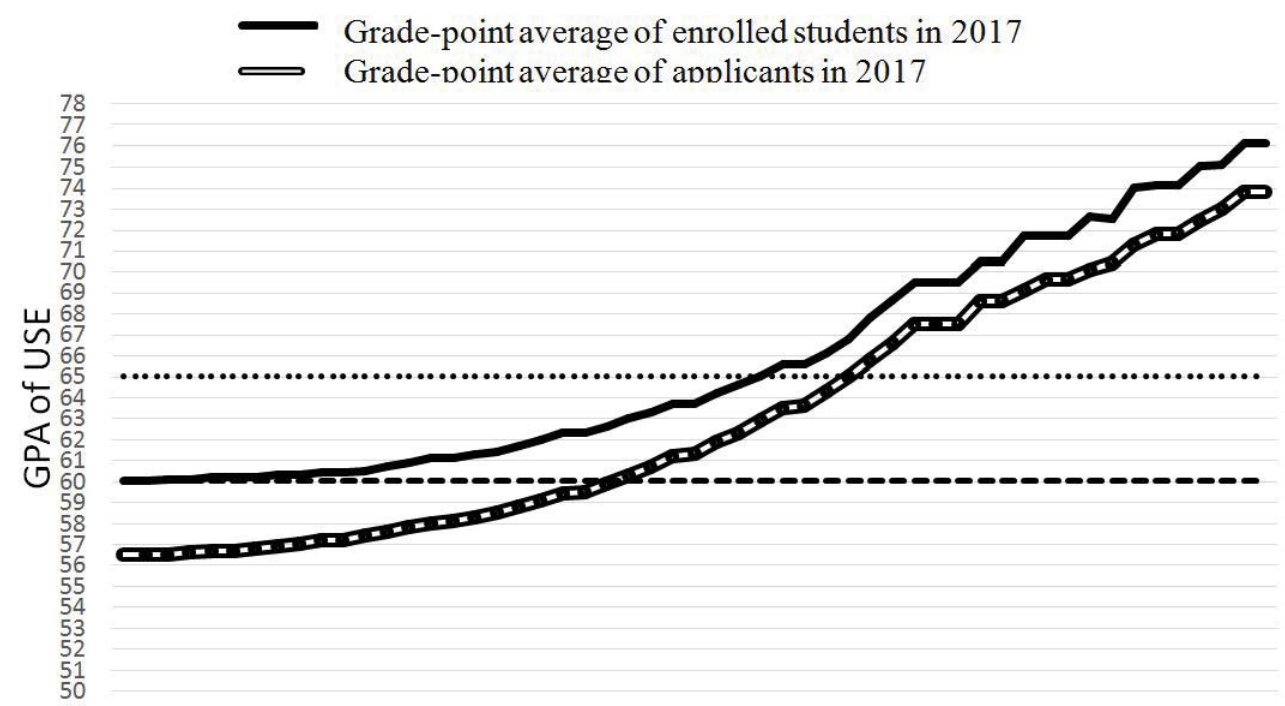

$\begin{array}{lllllllllllllllllllllllllll}38 & 40 & 42 & 44 & 46 & 48 & 50 & 52 & 54 & 56 & 58 & 60 & 62 & 64 & 66 & 68 & 70 & 72 & 74 & 76 & 78 & 80 & 82 & 84 & 86 & 88 & 90\end{array}$

Figure 1: Predicted USE GPA change of enrolled students at increase in threshold score in Russian language

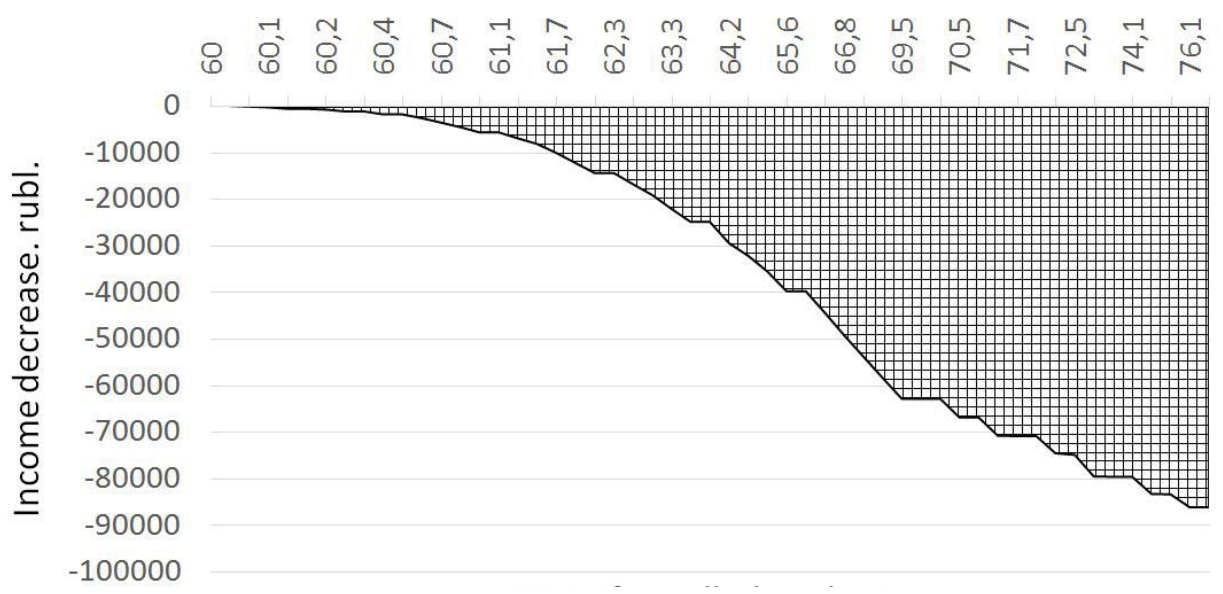

Figure 2: Assessment of decline income of higher education institution at increase in GPA

of enrolled students by increase in threshold score in Russian language

- Grade-point average of enrolled students in 2017

- Grade-point average of enrolled students in 2016

-.- Grade-point average of enrolled students in 2015

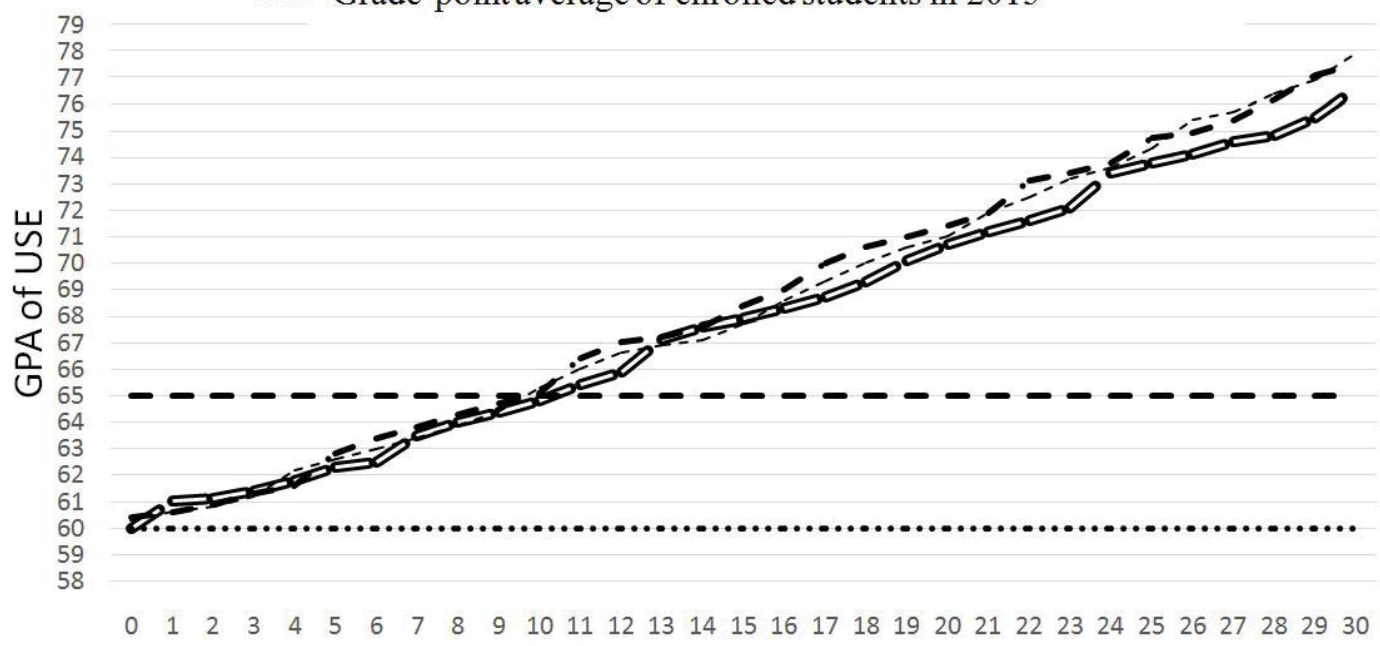

Figure 3: Predicted USE GPA change of enrolled students at increase in threshold score for each subject 


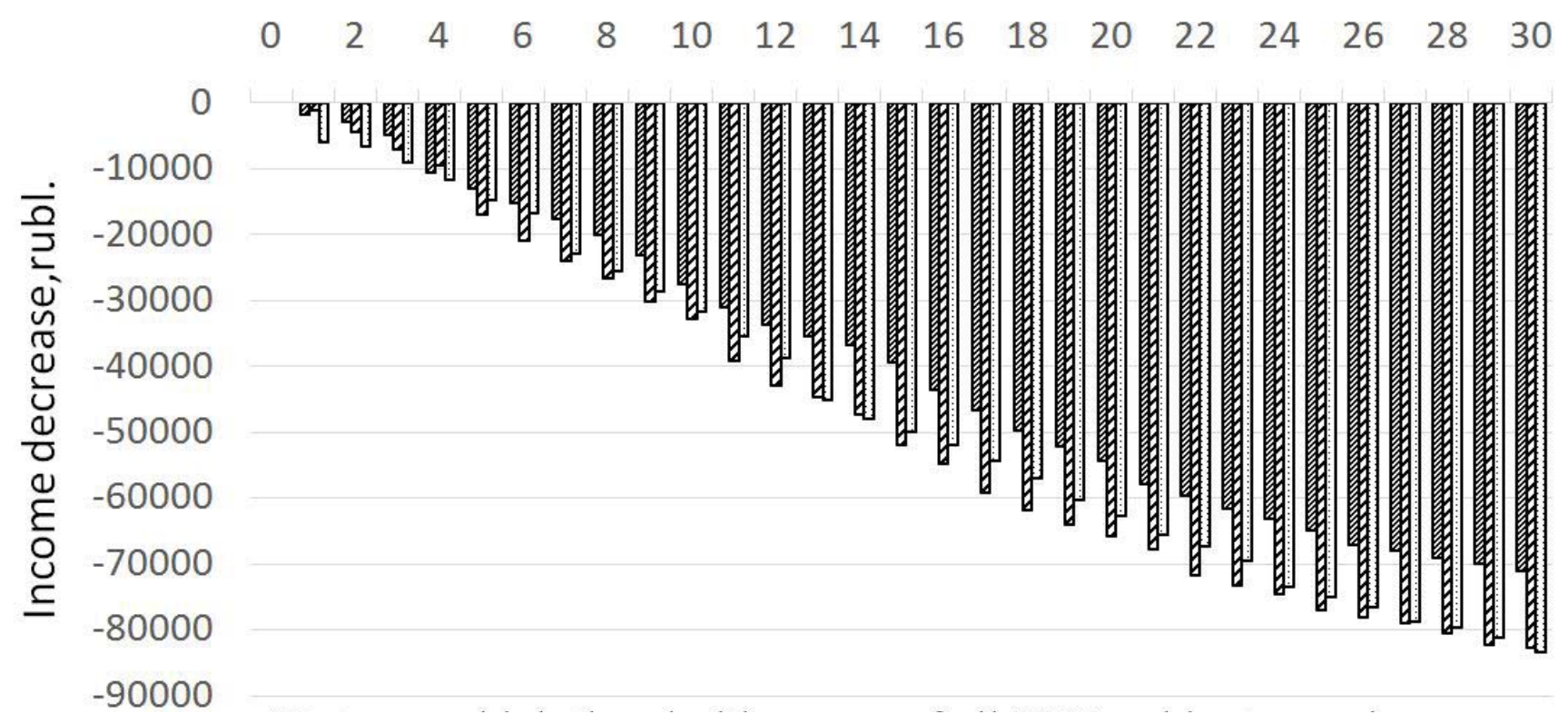

Figure 4: Assessment of income decline of higher education institution at increase in USE GPA by the increase in threshold scores for all subjects

\section{CONCLUSIONS}

It is possible to draw a conclusion that increase in USE GPA of enrolled students by threshold score change is economically inappropriate.

\section{REFERENCES}

1. Nurieva, L.M., Kiselev S.G. (2017) O chem govorit srednij ball EGE? (What does the average score of the unified state exam tell?), Obrazovanie i nauka, Vol. 19, Issue 6, pp. 33-51.

2. Isaev, V.G. Mihalishina E.V. (2015) Ocenka celesoobraznosti ispol'zovaniya srednego balla EGEH $v$ kachestve kriteriya ocenki kachestva obrazovatel'nogo processa (Evaluation of the feasibility of using the average score of the exam as a criterion for assessing the educational process), Perspektivy, organizacionnye formy i ehffektivnost' razvitiya sotrudnichestva rossijskih i zarubezhnyh vuzov, Tekhnologicheskij universitet, pp 181-186.

3. Ivanova, S.A. (2014) Problema EGE v rossijskom obrazovanii (Problem of USE in Russian education), Kul'tura. Duhovnost'. Obshchestvo, 10, pp 120-124.

4. Lagerev, R.Yu., Zedgenizov, A.V. (2013) Osobennosti ocenki obrazovatel'nogo rejtinga rossijskih gosudarstvennyh vuzov (Features of evaluation of the educational rating of Russian state universities), Sovremennye tekhnologii upravleniya, 8(32), pp 27 37
5. Chumanova, V.V. (2016) Chestno o monitoringe vuzov (Be honest about monitoring of the universities), Problemy prava, 3(57), pp 59-64.

6. Pyhtin, A.I., Emelianov, I.P. (2019) Prospects of creating a unified information system for admission to universities in Russia, International Journal of Recent Technology and Engineering, vol. 7(5), pp 299301

7. Ukolov, A.F., Apenina, S.A., Frundina, I.B. (2017) Edinyj gosudarstvennyj ehkzamen $v$ Kurskoj oblasti v 2017 godu. Sbornik statisticheskih materialov (Unified state exam in Kursk Region in 2017 year), Kursk: OOO «Planeta+», $492 \mathrm{p}$.

8. Storchevoj, V.F., Klyuev, A.N., Morozov, A.V. (2013) Kompleks meropriyatij, provodimyh MGUP po povysheniyu srednego balla EGE shkol'nikov pri postuplenii v vuz (The range of activities carried out MGUP to raise the average score of the exam students for admission to the university), Vestnik uchebno-metodicheskogo obedineniya po obrazovaniyu $v$ oblasti prirodoobustrojstva i vodopol'zovaniya, vol. 5(5), pp 77-85.

9. Kurylyova, O.I., Ogorodova, M.V., Kurylev, A.I. (2015) O razrabotke metodiki ocenki ehffektivnosti priemnoj kampanii vuza kak rezul'tata realizacii meropriyatij kompleksa proforientacionnogo vzaimodejstviya (On the development of a methodology for assessing the effectiveness of the admission campaign of the University as a result of the implementation of professional orientation of the complex interaction), Vestnik evrazijskoj nauki, vol. 7/issue 5(30), pp 204. 
10. Pykhtin, A.I., Ovchinkin, O.V. (2018) Mathematical model and algorithm of carrying out the centralized competition in Russian higher educational institutions, International Multidisciplinary Scientific GeoConference Surveying Geology and Mining Ecology Management, SGEM, vol. 18(2.1), pp 537-543

11. Ovchinkin, O.V., Pyhtin, A.I., Emelianov I.P. (2013) Algoritm processa upravleniya priemom lic na vtoroj i posleduyushchie kursy v vuzah, Izvestiya Yugo-Zapadnogo gosudarstvennogo universiteta (Proceedings of Southwest State University), vol. 1(46), pp 064-069. 